\title{
Integrating local hybrid knowledge and state support for climate change adaptation in the Asian Highlands
}

\author{
Jianchu Xu • R. Edward Grumbine
}

Received: 22 September 2013 / Accepted: 7 February 2014 / Published online: 2 March 2014

C The Author(s) 2014. This article is published with open access at Springerlink.com

\begin{abstract}
New hybrid forms of climate change adaptation combining local and nonlocal/ scientific knowledge are emerging across the Asian Highlands region. Yet, while local adaptive capacity can be based on place-based knowledge that governments often lack, communities still need assistance from states to better adjust to climate change and socioeconomic impacts. Using a regional literature review, we evaluate the role of evolving hybrid forms of adaptive knowledge for coping with environmental and social change. The literature is clear that appreciating local knowledge is not enough; enfranchising people with representative decision-making and resource rights and responsibilities is also required so that people can employ that knowledge toward climate adaptation. Into the future, Asian Highland climate change actions must include more targeted state support for locally evolving hybrid knowledge, behaviors and institutions.
\end{abstract}

\section{Introduction}

Over the past decade, the pace and magnitude of environmental and social transformation in the Asian Highlands have been accelerating due to global warming and increasing rates of socio-economic change. The highlands, stretching from the Afghanistan/Pakistan border in the west to northwest Yunnan, China in the east, form a vast mountainous area above 1,000 msl that includes the Himalaya-Tibetan Plateau. Climate change is already evident; warming in the Himalaya-Tibetan Plateau has been greater than two times the global average (Shrestha et al. 2012). Depending on location in the region, projections call for warming to increase by $1.5-$ $3{ }^{\circ} \mathrm{C}$ by 2040-2060 with greater changes by the end of the century (Gautam et al. 2013). Yu et al. (2010) report phenological shifts toward a shorter growing season on the Tibetan Plateau and Brandt et al. (2013) show large-scale vegetation shifts in progress. Across the highlands, many local people also observe such changes (Biggs and Watmough 2012; Haynes and Yang

\footnotetext{
J. Xu $\cdot$ R. E. Grumbine $(\bowtie)$

Key Laboratory for Plant Biodiversity and Biogeography of East Asia, Kunming Institute of Botany, Chinese Academy of Science, Kunming 650201 Yunnan, China

e-mail: ed.grumbine@gmail.com

J. Xu $\cdot$ R. E. Grumbine

World Agroforestry Center, East and Central Asia, Kunming 650201 Yunnan, China
} 
2013; Joshi et al. 2013), and more climate-extreme events and deterioration of ecosystem services are projected (World Bank 2013). These cumulative changes are increasing risks across a region often referred to as Asia's "Water Tower" since it is the source of waters that sustain over one billion people (Xu et al. 2009).

Yet, there is significant uncertainty about the regional climate record; climatological stations are sparse, often poorly maintained, and therefore do not accurately represent baseline conditions (Gautam et al. 2013). Because of the extreme topography and resulting complex climatic conditions, even high resolution models have yet to yield reliable projections of climate change and variation in the Asian Highlands.

Despite these uncertainties, the Asian Highlands continue to contribute water-related services to upstream and downstream communities and constitute a place for local knowledge-based adjustment to climate changes. For centuries, people have employed flexible systems for foraging and farming, trade, maintaining cultural identity, food security, and protecting genetic diversity using local knowledge and social networks as "bio-cultural refugia" (Barthel et al. 2013). With Asia booming, however, the intensity and magnitude of climatic and socio-economic changes pose significant challenges to the well-being of mountain peoples and the resilience of ecosystems. As change continues, scholars note that adaptation mechanisms based on local knowledge may be losing their effectiveness and some observers suggest that local climate adaptations may be inadequate to deal with future magnitudes of change (Lebel 2012).

While highland dwellers experience both threats and opportunities from climate variability and socioeconomic transformation, the effects of change in the Asian Highlands are deepened by the marginality of most inhabitants. About half of the 170 million people living in the highlands are poor, increasing their climate- related vulnerabilities (Chaudhary et al. 2012; Gentle and Maraseni 2012). Although indigenous people have been living in the highlands for centuries, most states in the region view them as "outsiders", subjects to be managed rather than citizens (Scott 2010). Governments, regardless of political system, tend to marginalize mountain peoples; rates of political participation and representation across the region are low. In addition, local knowledge is often seen by governments as less credible than scientific knowledge, despite the fact that peoples' perceptions of climate change conform closely to current scientific evidence (Byg and Salick 2009; Chaudhary and Bawa 2011). The consequences are an Asian Highlands that is stratified by social inequities as well as physical geography while being stressed by a changing climate.

These stratifications require that the terms vulnerability, (climate change) adaptation, and adaptive capacity be defined clearly due to lacunae in definitions and contests over meaning. Vulnerability is the risk of a negative outcome, such as hunger, famine, dislocation, or economic loss (Ribot 2010). Vulnerability often has multiple causes; it is important to identify the socio- political circumstances that generate it (Ribot 2011). For example, in Sikkim in the Indian Himalaya, villagers acknowledge the impacts of climate change but say that their vulnerability is affected more by lack of government support for education and health care (Barua et al. 2013). Climate adaptation can be defined broadly as processes where individuals, organizations, and societies adjust their behavior in response to current and expected changes (Adger et al. 2005; Smithers and Smit 1997). Adaptive capacity is the range of capabilities which people use to adjust to changes around them (Adger et al. 2007; Yohe and Tol 2002). With conditions in flux from locale to locale and from region to region, adaptive capacity includes how adaptations may help or hinder adjustment to new conditions (Engle 2011). One of the problems with the use all of these terms is that material questions of "how" are often focused upon to the exclusion of deeper socio-political questions of "why" (Lemos et al. 2013). 
In this paper, we review the regional literature on the evolving state of climate adaptation in the Asian Highlands as local people seek new forms of adjustment and governments help or hinder these processes. We then explore what the literature says as to why weak links persist between local adaptation and state support. We highlight findings that suggest how to bridge gaps between communities and governments to improve regional climate adaptation into the future. Currently, though there is growing global understanding of these issues, in the region there has been no review of how local adaptations are changing and how they are/are not linked to government policies.

\section{Methods}

\subsection{Literature- based inventory of local knowledge and adaptive practices}

To assess the current state of local knowledge and its role in climate change adaptation in the Asian Highlands, we performed a comprehensive regional literature review up through documents published into early 2014. We used the Web of Science, Science Direct and Google Scholar data bases to search for published work using the general keywords: "climate change adaptation". We then added "China", "Bhutan", "Nepal", "Pakistan", "India", "Indian Himalaya", "Asian Highlands", "Hindu Kush Himalaya" "Yunnan" and "hybrid knowledge" to the keyword template. In general for each search, we scanned the first 90-120 results after which we detected increasing repetition of citations and/or decreasing topic relevance. From this, we scrutinized @ 444 abstracts and selected 135 papers for in-depth analysis. The climate adaptation literature is large and expanding rapidly; we focused on the Asian Highlands and did not read extensively about studies conducted elsewhere. (We are aware, however, that most studies from other places do not contradict results described below-see Nakashima et al. 2012). To capture non-academic publications from governments, development agencies and NGOs, we searched references to this material from the papers chosen above and then read extensively. We also asked colleagues working on regional climate adaptation to recommend gray literature to review. We focused especially on country-specific evidence for local hybrid knowledge adaptation and government support (or lack thereof) for those behaviors. One limit to our search parameters is the lack of review of important literature describing evidence-based climate policy making and related research on decision theory (see UNEP 2013). We note a developing trend of papers published since@2008 that describe new hybrid forms of knowledge; little mention is made of this trend before this period. We also note that locallevel climate adaptation research and, therefore, published results, are not evenly distributed across Asian Highlands countries; China and Nepal are well-represented and Bhutan, India Pakistan and Afghanistan are not. We are in the midst of conducting a 3 year-long project that explores some of these issues (http://asianhighlands.org/), but results at this time are preliminary.

\section{Results}

\subsection{Local knowledge, adaptive capacity and the state}

Climate change adaptive capacity emerges from the needs of residents living in relation to specific local places (Adger et al. 2013). Given the history of uneven political power and representation in the Asian Highlands, local knowledge is often discounted because local 
people's objectives are often at odds with government goals (Blaikie and Muldavin 2004; Scott 1998). For example, local claims on natural resources are often downplayed since governments want to use them for national development. These conflicts often play out through state laws, policies and regulations that concentrate power with outside and/or lowland actors. Historical lack of educational opportunities and limited communication, infrastructure and market links from the highlands to the lowlands also contribute to inequities (see Dhungana and Wagle 2013).

Why has local knowledge persisted in the face of unequal power relations and globalization processes? One reason is that in remote regions like the Asian Highlands, governments lack on-the-ground capacity to regulate resources and govern citizens (Scott 1998). For example, states everywhere in Asia struggle to build and maintain urban infrastructure to support lowland centers of power, let alone sewers and water systems in distant rural areas (ADBI 2012). In addition, fine-scale local knowledge has the advantage of being already adapted to the spatial diversity and temporal variability of highland landscapes. In the face of "normal" rates of environmental and social change, local knowledge has proven resilient to changing conditions (Gurung et al. 2010).

Of course, just as the Asian Highlands are physically connected to the lowlands, the divide between outside power and local knowledge is not always so stark. No government in the Himalayan region is completely disinterested in local knowledge-based adaptive capacity. Many states support customary authority: examples include local councils in Pakistan, rural Village Development Committees in Nepal, and local village representation in highland regions of China. Some degree of discretionary power enables local authorities to respond flexibly to local needs. Local people also take advantage of their access to state-sanctioned knowledge and resources in pursuit of their objectives. But in the competition between "outside" and "local", political power is uneven and mountain people often remain at a disadvantage (Scott 2010).

\subsection{Current role of local knowledge in climate change adaptation}

Over the last decade or so, evidence is accumulating to show that Asian Highlands communities are increasingly dependent on outside inputs including state-sponsored infrastructure, market goods, services and renumeration, financial credit, extension services and meteorological information. Villagers are employing new blends of local knowledge, market access, and government program support - they are evolving hybrid forms of adaptive capacity where "bottom-up" behaviors are mixing with "top down" state policy in various, context-specific blends. The following are country-by-country examples from the literature that describe what hybrid adaptations to climate change look like across the Asian Highlands.

In Qinghai-Tibetan Plateau communities in China, pastoralists are adjusting grazing to accommodate new government sedentarization mandates; locally collecting more caterpillar fungus (Ophiocordyceps sinensis) to sell to distant urban markets; buying more commodities transported in from the outside; and leaving their homes to work in seasonal cash jobs (Fu et al. 2012; Haynes and Yang 2013). On the eastern edge of the Asian Highlands in northwest Yunnan province, farmers are adapting to climate-driven water stress through a mix of local knowledge (changing planting patterns), market dynamics (switching to commercial crop varieties) and government support (state-funded water storage) ( $\mathrm{Su}$ et al. 2012). In another area of Yunnan, Li and van Dijk (2012) discovered that five of 15 local knowledge-based climate adaptation actions (drought relief, water storage, irrigation infrastructure, etc.) were blended with government and /or private sector support. 
At pilot sites around Bhutan, local people are working with the government on disaster risk reduction plans (Meenawat and Sovacool 2012; Sovacool et al. 2012). Community members are taking outside expert- built climate risk models and blending these with local knowledge of hazards to rank risks.

In Nepal, foothill farmers are dealing with changing weather conditions by adapting indigenous cropping systems to new imported seed varieties with assistance from outside NGO partners (Singh et al. 2011). In other places, with advice from a international NGO, traditional land-use practices are being directed toward restoration of biodiversity in and around forests and protected areas (Chettri et al. 2012), and community decision making is being combined with expert-driven science to strengthen rangeland management (Dong et al. 2009).

For centuries in Pakistan, montane pastoralists have followed transhumance livelihoods but today, many nomads are increasingly dependent on ad hoc market/cash transactions during seasonal migrations (Rahim 2003). In another village, local awareness of site-specific climate risks is being incorporated into a NGO-supported community disaster risk management plan though government support is lacking (Nizami et al. 2009). In the northwest, international NGOs have been working with villagers and their leaders to manage state forests using a blend of local, expert and government knowledge (Shahbaz et al. 2011).

Government programs to enhance climate change adaptation in highlands India have shown greater effectiveness when villagers engage with the state on common projects; the mix of "top down" to "bottom up" differs from place to place (Bhave et al. 2013). At locations in India, Pakistan and Nepal, there are programs that link local knowledge of ecological conditions with expert-based climate change understanding to enhance education for village children (Sterrett 2011).

The above research shows that Asian Highlands people already recognize that local knowledge is not sufficient as the sole means to support ongoing adjustment to climate change. As outside forces become more powerful drivers of change, local people understand that they may not have the insights and abilities to adjust on their own (Brunner and Lynch 2010). Especially over the last decade, they have responded by rearranging their adaptation strategies to include more dependence on outside technology, markets and governments. People have not given up traditional practices; they have added in more market and state support to reduce local risks and bolster adaptive capacity. Despite their poverty, relative lack of political representation and limited scientific understanding, people in the Asian Highlands are developing hybrid forms of climate change adaptation that are neither wholly local nor government-based. This process is similar to, but not the same as, processes described by Alexander et al. (2010) and Armitage et al. (2011) where multiple actors "co-produce" new adaptive knowledge by design. In the Asian Highlands, such co-production is occurring, but hybrid knowledge is also generated in reaction to events without much foresight or planning. Highlanders are developing hybrid adaptations because they live on the ground where changes are occurring and, other than out-migration, they have little choice but to adjust as best they can.

\subsection{Barriers between local adaptation actions and state decisions}

Hybrid combinations of climate change adaptation are not going to disappear. Asian Highlanders will continue to buy non-local seeds, tools and fertilizers, export their products and labor to outside markets, and benefit from government and NGO support. But at the same time that hybrid knowledge appears increasingly essential to local climate change adaptation, the regional literature reveals much evidence of direct and indirect lack of government support for locally-based adaptation: 
In western China, herders' ability to use local knowledge to adapt to climate change is constrained by the central government's top-down Grasslands Retirement System (Cao et al. 2013). In the mountains of southwest China, the central governments' massive Grain-ForGreen program of planting trees on sloping lands has not used local knowledge much nor is it well-integrated into local watershed plans (Kemp et al. 2013).

Ongoing government instability in Nepal is so pervasive that, despite the presence of national climate action plans that specifically endorse local knowledge, the state has little capacity to help implement local climate adaptation (Bartlett et al. 2010; Regmi and Bhandari 2012). State behavior is not the only problem; local social barriers to adaptation also exist (Jones and Boyd 2011). And, at times, outside donor goals and operating procedures undercut local adaptation (Biggs et al. 2013; Dhungana and Wagle 2013).

In Pakistan, governments respond to more frequent extreme events by spending larger sums on relief and rehabilitation; support for less costly disaster preparedness remains low (ICIMOD 2010). With local people increasingly unable to predict crop planting periods, government extension institutions appear to be less responsive to the pace of climate-induced change. As in Nepal, local knowledge of resources and climate vulnerabilities has not yet been wellintegrated into development planning (Joshi et al. 2013); from the one study that we could find, the same appears to be the case in Afghanistan (Shaoliang et al. 2012).

In India, though stakeholder engagement has been shown to increase effectiveness in assessing local climate vulnerabilities, it is still uncommon to see the government supporting local participation. In the Indian Himalaya, for example, most hydropower development plans lack any input from local peoples (Grumbine and Pandit 2013).

These examples highlight the importance of a multi-level approach to climate change adaptation. They also show that, even as mountain people gain benefits from an expanding array of hybrid strategies, new forms of local-level climate change adaptation often remain ad hoc and are not yet articulated well with state-led decision-making (Rodima-Taylor et al. 2012).

3.4 Missing links between local knowledge and state decisions: national action plans for climate change

Lack of linkages between local knowledge and state-led decision making are obvious when reviewing national action plans for climate change in the Asian Highlands. These plans are part of the United Nations Framework Convention on Climate Change (UNFCCC 2011) and use aggregated data to outline steps that governments may take to address climate change impacts; details differ from country to country. We focus here on literature analyzing plans from the three countries where we are currently conducting research: China, Nepal, and Pakistan.

In these countries, every plan mentions support for local adaptation but none provide specific links between national-level policy support and local implementation. In China, the National Climate Change Programme and associated provincial-level documents discuss the role of conservation and development in local climate adaptation (DRC TAR 2009; NDRC 2007). However, decision-making remains top-down and tends to preclude local participation (Chen et al. 2014; Gemmer et al. 2011). In 2011, Pakistan completed a draft national Climate Action Policy, but it has not yet been released. The draft supports creation of a Global Climate Studies Centre but it is research -based and not linked to local knowledge (Sterrett 2011).

Nepal launched a climate change National Adaptation Program of Action in 2010. This plan is connected to Local Adaptation Plans of Action that explicitly call for a bottom-up, inclusive approach. While these plans promise to target $80 \%$ of state funding for local-level climate action, no implementation scheme is provided, hence there is little local ownership or action (Watt 2012). 
There are several current projects underway in Nepal where integration between local adaptation and state decisions does show promise. In Pokhara, a national NGO is acting in concert with local people to link climate decision making between upstream and downstream communities and their governments (Sterrett 2011). Another project explicitly seeks to use direct advocacy with national policy makers in an effort to mainstream local climate adaptation knowledge (Chaudhary et al. 2012). But these represent only several out of 64 reviewed projects (Sterrett 2011). Data from India tell the same story; despite national plans that were completed 3-5 years ago, few links between state climate planning and local adaptations have been established (Singh et al. 2012).

\subsection{Linking government policy with local climate adaptation hybrid strategies}

There is broad agreement in the Asian Highlands literature that local climate change adaptation is improved through more coordinated and targeted government policy support (Aase et al. 2013; Brooks et al. 2012; Huntjens et al. 2011). Given that climate change impacts are projected to intensify, now is the time to experiment with pilot projects that can 1) assess what works and what does not across multiple scales and conditions and 2) look for cross-scale linkages that increase efficiencies in local practices and state decision making. The most common recommendations raised by researchers include:

1) More open communication between experts, governments and local peoples (OpitzStapleton 2010; Yates 2012). This is especially important for the communication of climate science in culturally sensitive ways (Azhar-Hewitt and Hewitt 2012; OpitzStapleton and MacClune 2012; Ross and Berkes 2013).

2) Better prioritization given to the most climate-vulnerable groups including women, the poor, ethnic minorities, and people living in fragile habitats (riversides, steep slopes, etc.) (Becken et al. 2013; Jones and Boyd 2011).

3) Targeted economic investment especially for: community water infrastructure ( $\mathrm{Su}$ et al. 2012); cooperatives with market chains for village-produced products (Piya et al. 2013); household-scale investment in solar energy (Fang and Wei 2013); carbon finance programs for farmers and herders ( $\mathrm{Xu}$ et al. 2006); and climate-risk insurance and microfinance to help the poor gain access to capital (Dulal 2010).

4) Improved disaster planning that links risk management with local natural resource use (Nizami and Robledo 2010; Schipper 2009).

5) Revamped agricultural extension services involving farmer-to-farmer diffusion (Biggs and Watmough 2012) and more financial support for soil conservation (Liu and Huang 2013). Recommendations also include climate awareness education for adults and school science programs geared to local cultural conditions (Bartlett et al. 2010).

6) Enhanced political representation to support more secure land and resource tenure (Larsen and Dahal 2012) and local representation in decision-making (Lemos et al. 2013; Singh et al. 2012).

\section{Discussion and conclusion}

In the Asian Highlands, a more integrated approach that blends strategies to secure more resource access for local people could pave pathways toward successful climate adaptation, more inclusive governance, and greater state stability. To accomplish this, leaders would have 
to reframe state-led decisions as more ecological, efficient, and equitable means of managing risks in an increasingly uncertain world. For governments, this means understanding that without the benefits of 'bottom-up' adaptation built on hybrid knowledge and innovation, climate change impacts are more likely to decrease social and economic stability (Grumbine 2014; Upreti et al. 2013).

There are two important drivers for governments to move faster to scale up the above strategies from short-term "coping" to long-term "adapting" to climate change. First, because climate adaptation behaviors are different between and within countries, national aggregated data is not dependable as a basis for supporting specific actions. To build better integration between local actions and government policy, one size does not fit all. Second, local governments appear to be key reframing actors for hybrid adaptation since they are in a position that may allow them to be responsive to both central authorities and local communities ( $\mathrm{Fu}$ et al. 2012).

Over the longer term, highlanders require more than programmatic government support for hybrid climate adaptations. They need more equitable political/legal relationships with outsiders (Williams and Hardison 2013) and some discretionary power over local resource use decisions (Amaru and Chhetri 2012). Access to land and water resources may increase as governments provide more support to hybrid/co-produced forms of climate change adaptation. Representation at higher levels of policy making will take more time; in the Asian Highlands, despite some progress in some countries, states are still saddled with inequitable frames of governance and low capacity that limit both adaptation and equality. Looking for leverage points to advance climate change adaptation under these political conditions will remain challenging.

Data from the Asian Highlands on these points are in general agreement with lessons learned elsewhere. For example, studies conducted in the Americas, northern latitudes, and small islands show the importance of knowledge co-production and state support for traditional/local climate adaptations (Nakashima et al. 2012; Wildcat 2013). Global data also reinforce observations that lack of government support for local adaptations is not just a regional problem (Agrawal et al. 2012). Mapping, measuring and monitoring local vulnerability, integrating local and state responses to change, support for community capacity building, systematic identification of successful climate adaptations, building better sociopolitical understanding of how risks are perceived and climate adaptation decisions are made - all of these bolster adaptive capacity and point toward work to do that remains challenging in the Asian Highlands and beyond (UNEP 2013).

The Asian Highlands have always been affected by climate variability, yet mountain dwellers have adapted and continue to adapt. But neither exclusive top-down nor bottom-up climate adaptation strategies really work anymore. The literature shows that in complex socialecological systems, there are few examples of climate adaptation that depend only on local knowledge, government programs or any other single form of support. Adaptation is not simply the result of fixed cultural beliefs and customs; local knowledge evolves and will always involve negotiations among multiple social actors manifest as continuous learning processes. Therefore, in order to better understand linkages between biophysical changes and social drivers of vulnerability in service of reducing risks and increasing adaptive capacity across scales, it is imperative to engage highland peoples. Slowness to embrace change may lead to less state and social stability as risks increase and ecological services decline.

Across the Asian Highlands and beyond, these observations suggest three adaption pathways toward the future. First, in the context of reducing risks from climate change for both communities and governments, more effort must be made to sensitize leaders and policy makers to the interface between local and national interests. One promising approach is 
adaptive development, where climate adaptations are integrated into mainstream development policy (Lemos et al. 2013). Second, government policy should avoid blanket solutions and target specific hybrid knowledge systems in specific places. Third, enhanced political representation with significant resource control for highlands peoples must be established sooner rather than later. The literature is quite clear that such measures can help communities and countries to adapt better to ongoing climatic and social change. These actions may also serve the building of stronger relationships between people at the center and periphery, upstream and downstream, and all across the Asian Highlands.

Acknowledgments Research was part of IDRC- supported project on "Building Effective Water Governance in the Asian Highlands". Additional support is also from CGIAR Research Program 7: Climate Change, Agriculture and Food Security (CCAFS). REG wishes to thank the Chinese Academy of Sciences (Grant 2010T1S2) for his Visiting Professorship for senior international scientists. Jesse Ribot provided valuable comments on an early version of the manuscript.

Open Access This article is distributed under the terms of the Creative Commons Attribution License which permits any use, distribution, and reproduction in any medium, provided the original author(s) and the source are credited.

\section{References}

Aase T, Chapagain P, Tiwari P (2013) Innovation as an expression of adaptive capacity to change in Himalayan farming. Mt Res Dev 33:4-10

ADBI (2012) Policies and practices for low-carbon green growth in Asia. Asian Development Bank Institute, Manilla

Adger WN, Arnell W, Tompkins L (2005) Successful adaptation to climate change across scales. Glob Environ Chang 15:77-86

Adger WN, Agrawala S, Mirza M, Conde C, O’Brien K, Pulhin J, Pulwarty R, Smit B, Takahashi K (2007) Assessment of adaptation practices, options, constraints and capacity. In: Parry $\mathrm{M}$ et al (eds) Climate change 2007: impacts, adaptation and vulnerability. Contribution of working group II to the Fourth Assessment Report of the Intergovernmental Panel on Climate Change. Cambridge University Press, Cambridge, pp 717-743

Adger WN, Barnett J, Brown K, Marshall N, O’Brien K (2013) Cultural dimensions of climate change impacts and adaptation. Nat Clim Chang 3:112-117

Agrawal A, Perrin N, Chhatre A, Benson C, Kononen M (2012) Climate policy processes, local institutions, and adaptation actions: mechanisms of translation and influence. Wiley Interdiscip Rev Clim Chang 3:565-579

Alexander C, Bynum N, Johnson E, King U, Mustonen T, Neofotis P, Oettlé N, Rosenzweig C, Sakakibara C, Shadrin V, Vicarelli M, Waterhouse J, Weeks B (2010) Linking indigenous and scientific knowledge of climate change. Bioscience 61:477-484

Amaru S, Chhetri N (2012) Climate adaptation: institutional responses to environmental constraints, and the need for increased flexibility participation, and integration of approaches. Appl Geogr 39:128-139

Armitage D, Berkes F, Dale A, Kocho-Schellenberg E, Patton E (2011) Co-management and the co-production of knowledge: learning to adapt in Canada's Arctic. Glob Environ Chang 21:995-1004

Azhar-Hewitt F, Hewitt K (2012) Technocratic approaches and community contexts: viewpoints of those most at risk from environmental disasters in mountain areas, Northern Pakistan. In: Lamadrid A, Kelman I (eds) Climate change modeling for local adaptation in the Hindu KushHimalayan region (community, environment and disaster risk management), vol 11. Emerald Group, Bingley, pp 53-73

Barthel S, Crumley C, Svedin U (2013) Bio-cultural refugia- safeguarding diversity of practices for food security and biodiversity. Glob Environ Chang. doi:10.1016/j.gloenvcha.2013.05.001

Bartlett R, Bharati L, Pant D, Hosterman H, McCormick P (2010) Climate change impacts and adaptation in Nepal. Working paper 139, International Water Management Institute, Colombo, Sri Lanka

Barua A, Katyaini S, Mili B, Gooch P (2013) Climate change and poverty: building resilience of rural mountain communities in South Sikkim, Eastern Himalaya, India. Reg Environ Chang. doi:10.1007/s10113-0130471-1 
Becken S, Lama A, Espiner S (2013) The cultural context of climate change impacts: perceptions among community members in the Annapurna Conservation Area, Nepal. Environ Dev. doi:10.1016/j.envdev.2013. 05.007

Bhave A, Mishra A, Groot A (2013) Sub-basin scale characterization of climate change vulnerability, impacts and adaptation in an Indian River basin. Reg Environ Chang. doi:10.1007/s10113-013-0416-

Biggs E, Watmough G (2012) A community-level assessment of factors affecting livelihoods in Nawalparasi District, Nepal. J Int Dev 24:255-263

Biggs E, Tompkins E, Allen J, Moon C, Allen R (2013) Agricultural adaptation to climate change: observations for the Mid-Hills of Nepal. Clim Dev 5:165-173

Blaikie P, Muldavin J (2004) Upstream, downstream, China, India: the politics of environment in the Himalayan Region. Ann Assoc Am Geogr 94:520-548

Brandt J, Haynes M, Kuemmerle T, Waller D, Radelof V (2013) Regime shift on the roof of the world: alpine meadows convert to shrublands in the southern Himalayas. Biol Conserv 158:116-127

Brooks J, Waylen K, Mulder M (2012) How national context, project design, and local community characteristics influence success in community-based conservation projects. Proc Natl Acad Sci U S A 109:21265-21270

Brunner R, Lynch A (2010) Adaptive governance and climate change. American Meterological Society, Boston

Byg A, Salick J (2009) Local perspectives on global phenomenon-climate change in Eastern Tibetan villages. Glob Environ Chang 19:156-166

Cao J, Yeh E, Holden N, Yang Y, Du G (2013) The effects of enclosures and land use contracts on rangeland degradation on the Qinghai-Tibetan plateau. J Arid Environ 97:3-8

Chaudhary P, Bawa K (2011) Local perceptions of climate change validated by scientific evidence in the Himalayas. Biol Lett 7:767-770

Chaudhary P, Thapa K, Lamsal K, Tiwari P, Chhetri N (2012) Community-based climate change adaptation for building local resilience in the Himalayas. In Tech. doi:10.5772/50608

Chen H, Wang J, Huang J (2013) Policy support, social capital, and farmers' adaptation to drought in China. Glob Environ Chang. doi:10.1016/j.gloenvcha.2013.11.010

Chettri N, Sharma E, Zomer R (2012) Changing paradigms and post 2010 targets: challenges and opportunities for biodiversity in the Hindu Kush Himalaya. Trop Ecol 53:245-259

Dhungana S, Wagle R (2013) How climate change discourses are negotiated at meso level: revisiting annual development planning in Nepal. J For Livelihood 11:29-42

Dong S, Lassoie J, Shrestha KK, Yan Z, Shan E, Pariya D (2009) Institutional development for sustainable rangeland resource and ecosystem management in mountainous areas of northern Nepal. J Environ Manag 90:994-1003

DRC-TAR (2009) China's policies and actions on climate change: the prefectural plan of Tibetan Autonomous Region, Development and Reform Commission of the Tibetan Autonomous Region TAR, Lhasa (in Chinese)

Dulal H (2010) Do the poor have what they need to adapt to climate change? A case study of Nepal. Local Environ 15:621-635

Engle N (2011) Adaptive capacity and its assessment. Glob Environ Chang 21:647-656

Fang Y, Wei Y (2013) Climate change adaptation on the Qinghai-Tibetan Plateau: the importance of solar energy utilization for rural household. Renew Sustain Energy Rev 18:508-518

Fu Y, Grumbine RE, Wilkes A, Wang Y, Xu J, Yang Y (2012) Climate change adaptation among Tibetan pastoralists: challenges in enhancing local adaptation through policy support. Environ Manag 50:607-621

Gautam M, Govinda R, Timilsina R, Acharya K (2013) Climate change in the Himalayas: current state of knowledge. Policy research working paper 6516. World Bank, Washington DC

Gemmer M, Wilkes A, Vaucel L (2011) Governing climate change adaptation in the EU and China: an analysis of formal institutions. Adv Clim Chang Res 2:1-11

Gentle P, Maraseni T (2012) Climate change, poverty, and livelihoods: adaptation practices by rural mountain communities in Nepal. Environ Sci Pol 21:24-34

Grumbine RE (2014) In press. Assessing environmental security in China. Front Ecol Environ

Grumbine RE, Pandit R (2013) Threats from India's Himalaya dams. Science 339:34-35

Gurung G, Pradhananga D, Karmacharya D, Subedi J, Gurung A, Shrestha S (2010) Impact of climate changevoices of people: based on field observations, information and interactions with the communities in Nepal. Practical Action, Kathmandu. http://cdn1.practicalaction.org/i/m/4f269ff8-7d04-4621-935d-7ce41661b3dc.pdf

Haynes M, Yang Y (2013) Adapting to change: transitions in traditional range management of Tibetan yak herders in northwest Yunnan. Environ Dev Sustain 15:1065-1077

Huntjens P, Pahl-Wostl C, Rihoux B, Schluter M, Flachner L, Neto S, Koskova R, Dickens C, Nabide-Kiti I (2011) Adaptive water management and policy learning in a changing climate. A formal comparative analysis of eight water management regimes in Europe, Asia and Africa. Environ Policy Gov 21:145-163 
ICIMOD (2010) Islamic Republic of Pakistan: glacial melt and downstream impacts on Indus dependent water resources and energy. International Centre Integrated Mountain Development, Kathmandu

Jones L, Boyd E (2011) Exploring social barriers to adaptation: insights from Western Nepal. Glob Environ Chang 21:1262-1274

Joshi S, Dasra W, Ismail M, Shrestha R, Yi S, Wu L (2013) Herders' perceptions of and responses to climate change in northern Pakistan. Environ Manag. doi:10.1007/s00267-013-0062-4

Kemp D, Guodong H, Xiangyang H, Michaelk DL, Fujinag H, Jianping W, Yingjun Z (2013) Innovative grassland management systems for environmental and livelihood benefits. Proc Natl Acad Sci U S A 110: 8369-8374

Larsen A, Dahal G (2012) Forest tenure reform: new rights for forest-based communities? Conserv Soc 10:77-90

Lebel L (2012) Local knowledge and adaptation to climate change in natural resource-based societies of the AsiaPacific. Mitig Adapt Strateg Glob Chang. doi:10.1007/s11027-012-9407-1

Lemos M, Agrawal A, Johns O, Eakin H, Nelson D, Engle N (2013) Building adaptive capacity in less developed countries. In: Asrar G, Hurrell J (eds) Climate science for serving society. Springer, Netherlands, pp 437-457

Li H, van Dijk M (2012) Climate change and farmers responses in rural China. Int J Water 6:290-310

Liu H, Huang Q (2013) Adoption and continued use of contour cultivation in the highlands of southwest China. Ecol Econ 91:28-37

Meenawat H, Sovacool B (2012) Bhutan: modeling and adaptation in the eastern Himalayas. In: Lamadrid A, Kelman I (eds) Climate change modeling for local adaptation in the Hindu Kush-Himalayan region (community, environment and disaster risk management), vol 11. Emerald Group, Bingley, pp 141-158

Nakashima DJ, McLean KG, Thulstrup HD, Castillo AR, Rubis J (2012) Weathering uncertainty: traditional knowledge for climate change assessment and adaptation. UNESCO, and Darwin, UNU, Paris

NDRC (2007) China's national climate change programme. National Development and Reform Commission, Beijing

Nizami A, Robledo C (2010) Natural resource management and climate change mitigation, adaptation and REDD+. Part four: adaptation to climate change. Intercooperation Pakistan, Islamabad. http://www. intercooperation.org.pk/uploads/4-adaptation.pdf

Nizami A, Hussain I, Saleem M (2009) Climate change, early signs and warning systems. The villagers' account. Briefing Note 02, Livelihoods Programme. Intercooperation, Pakistan, Islamabad. http://www. intercooperation.org.pk/uploads/CC-and-early-signs.pdf

Opitz-Stapleton S (2010) Only death is certain, yet you still get out of bed in the morning: observations on the use of climate information in adaptation and resilience practice. Climate Resilience in Concept and Practice. Working Paper Series. ISET, Boulder, Colorado

Opitz-Stapleton S, MacClune K (2012) Scientific and social uncertainties in climate change: the Hindu KushHimalaya in regional perspective. In: Lamadrid A, Kelman I (eds) Climate change modeling for local adaptation in the Hindu Kush-Himalayan region (community, environment and disaster risk management), vol 11. Emerald Group, Bingley, pp 141-158

Piya L, Maharjan K, Joshi N (2013) Determinants of adaptation practices to climate change by Chepang households in the rural Mid-Hills of Nepal. Reg Environ Chang 13:437-447

Rahim I (2003) Pastoral systems in Hindukush-Himalayas of northern Pakistan. Sungi Development Foundation, Pakistan. http://fresh.org.pk/images/Pubs/Pastoral\%20Use\%20Pattern\%20SUNGI\%20Study.pdf

Regmi B, Bhandari D (2012) Climate change governance and funding dilemma in Nepal. TMC Acad J 7:40-55

Ribot J (2010) Vulnerability does not fall from the sky: toward multiscale, pro-poor climate policy. In: Mearns R, Norton A (eds) Social dimensions of climate change. World Bank, Washington DC, pp 47-74

Ribot J (2011) Vulnerability before adaptation: toward transformative climate action. Glob Environ Chang 21: $1160-1162$

Rodima-Taylor D, Olwig M, Chhetri N (2012) Adaptation as innovation, innovation as adaptation: an institutional approach to climate change. Appl Geogr 33:107-111

Ross H, Berkes F (2013) Community resilience: toward an integrated approach. Soc Nat Resour 26:5-20

Schipper E (2009) Meeting at the crossroads: exploring the linkages between climate change adaptation and disaster risk reduction. Clim Dev 1:16-30

Scott J (1998) Seeing like a state. Yale University Press, New Haven

Scott J (2010) The art of not being governed: an anarchist history of Upland Southeast Asia. Yale University Press, New Haven

Shahbaz B, Ali T, Soleri A (2011) Dilemmas and challenges in forest conservation and development interventions: case of Northwest Pakistan. For Policy Econ 13:473-478

Shaoliang Y, Ismail M, Zhaoli Y (2012) Pastoral communities perspectives on climate change and their adaptive strategies in the Hindukush-Karakoram-Himalaya. In: Kreutman H (ed) Pastoral practices in High Asia. Advances in Asian human-environment research. Springer, Netherlands, pp 307-322 
Shrestha U, Gautam S, Bawa K (2012) Widespread climate change in the Himalayas and associated changes in local ecosystems. PloS ONE 7:e36741

Singh S, Bassignana-Khadka I, Karky B, Sharma E (2011) Climate change in the Hindu Kush Himalayas- the state of current knowledge. International Centre for Integrated Mountain Development, Kathmandu

Singh N, Bantilan M, Byjesh K, Murty M (2012) Vulnerability to climate change: adaptation strategies and layers of resilience. Policy Brief No. 17. International Crops Research Institute for the Semi-Arid Tropics, Andhra Pradesh, India

Smithers J, Smit B (1997) Human adaptation to climatic variability and change. Glob Environ Chang 7:129-146

Sovacool B, D'Agostino A, Meenawat H, Rawlani A (2012) Expert views of climate change adaptation in least developed Asia. J Environ Manag 97:78-88

Sterrett C (2011) Review of climate change adaptation practices in South Asia. Oxfam Research Report, Climate Concern, Melbourne

Su Y, Xu J, Wilkes A, Lu J, Li Q, Fu Y, Ma X, Grumbine RE (2012) Coping with climate-induced water stress through time and space in the mountains of southwest China. Reg Environ Chang 12:855-866

UNEP (2013) Research priorities on vulnerability, impacts and adaptation. Responding to the climate change challenge. United Nations Environment Programme, Nairobi

UNFCCC (2011) Report of the Conference of the Parties on its 16th Session. United Nations Framework Convention on Climate Change, Bonn

Upreti B, Bhattarai R, Wagle G (2013) Human security in Nepal: concepts, issues and challenges. Nepal Institute for Policy Studies and South Asia Regional Coordination Office of NCCR (North-south), Kathmandu

Watt R (2012) Linking national and local adaptation planning: lessons from Nepal, case study 3 . The Learning Hub, Institute of Development Studies, Brighton

Wildcat DR (2013) Introduction: climate change and indigenous peoples of the USA. Clim Chang 120:509-515

Williams T, Hardison P (2013) Culture, law, risk and governance: contexts of traditional knowledge in climate change adaptation. Clim Chang 120:531-544

World Bank (2013) Turn down the heat: climate extremes, regional impacts, and the case for resilience. A report for the World Bank by the Potsdam Institute for Climate Impact Research and Climate Analytics. World Bank, Washington, DC

Xu JT, Yin R, Li Z, Liu C (2006) China's ecological rehabilitation: unprecedented efforts, dramatic impacts and requisite policies. Ecol Econ 57:595-607

Xu J, Grumbine RE, Shrestha A, Eriksson M, Yang X, Wang Y, Wilkes A (2009) The melting Himalayas: cascading effects of climate change on water, biodiversity and livelihoods. Conserv Biol 23:520-530

Yates J (2012) Uneven interventions and the scalar politics of governing livelihood adaptation in rural Nepal. Glob Environ Chang 22:537-546

Yohe G, Tol R (2002) Indicators for social and economic coping capacity-moving toward a working definition of adaptive capacity. Glob Environ Chang 12:24-40

Yu H, Luedeling E, Xu J (2010) Winter and spring warming result in delayed spring phenology on the Tibetan Plateau. Proc Natl Acad Sci U S A 107:22151-22156 